\title{
Teachers' Problematic In Disseminating Information On Sex Education for Adolescents with Disabilities Through Mass Media
}

\author{
Yanti Setianti \\ Communication Faculty \\ Padjadjaran University \\ Bandung Indonesia \\ Aat Nugraha \\ Communication Faculty \\ Padjadjaran University \\ Bandung Indonesia
}

\author{
Hanny Hafiar \\ Communication Faculty \\ Padjadjaran University \\ Bandung Indonesia
}

Trie Damayanti

Communication Faculty

Padjadjaran University

Bandung Indonesia

\begin{abstract}
Schools, as education institutions have an important role in educational efforts, including education about health reproductive for their students. As a specialized educational institution for students with intellectual disability, SLB C has its own challenges in providing education about reproductive health. Whereas in SLB C equivalent to Junior High School level, the students have entered the age of puberty. On the other hand, the pattern of education conducted by the SLB cannot be made only to the student, but also to the parents of the students, because consider to the students with the intellectual disability has a different understanding ability. Some teachers are hoping to be able to disseminate information relating to the reproductive health education for teenagers with the intellectual disability through the mass media, to be accessible directly by parents who have children with special needs. However, there are a few problems still become the constraint, so that those activities have not been implemented optimally. Therefore, this research aims to do mapping with respect to the problems encountered by the school in conducting information dissemination concerning education about reproductive health education for disability teenagers through the mass media. The method used is descriptive qualitative with the techniques of data collection through interviews and observations. As for the results obtained include: technical barriers, consisting of scientific articles technical writing and article technical submissions to the mass media; as well as psychological barriers perceived by the teachers in information dissemination through the mass media.

Keywords: education, reproductive health, disability students, scientific articles, mass media.
\end{abstract}

\section{INTRODUCTION}

Information is the important thing in people's lives. According to Chen and Chernon (Pannen, 1990:31), information needs will occur if the uncertain circumstances arising as a result of the occurrence of a gap or gap in man between knowledge possessed by the information it needs. Therefore, individuals will seek information to meet their needs for these disparities, human use or attempted use of various resources (Saepudin, 2013).

The ability to use information to meet the needs and resolve the problems encountered in everyday life can be referred as information literacy. Definition of information literacy can be translated into be aware of information, or in Indonesia some call as keberinformasian (english: information literacy). (Bahtar, et al., 2009 and Sudarsono 2007). Meanwhile, according to Wesleyan University, information literacy is:

" a crucial skill in the pursuit of knowledge. It involves recognizing when information is needed and being able to efficiently locate, accurately evaluate, effectively use, and clearly communicate information in various formats." From these definitions can be interpreted that information literacy is an important skill in search of knowledge, which includes being aware when information is needed and can be found efficiently, evaluated, used effectively, and communicated clearly in their environment (Suwanto, 2015).

Without information, people will not be developed and cultured. Civilized society is a society that has the capability of information literacy. Information literacy in addition to be able to absorb the information, it is also capable of producing the information. Information in the world of education has an important role. The materials and techniques to educate students learners can be known from the information into the stock of knowledge. Almost all the educators have the ability to absorb information, but not all are capable of producing information and publish it to the public. Whereas the skills to make the scientific work is one of the skills that must be possessed by teachers as proposed by Rooijakkers (1991: 189-228) in his book titled "Teaching with 
Success" gives instructions to a teacher who would like to teach with success, namely:

"... one of the teacher's skill is in making scientific papers or other writings which aimed to facilitate the occurrence of the learning process on the part of students. The teacher is not enough to just talk in advance of the class, but the effort needs to be coupled by communicating through media such as modules, diktat, papers or scientific writings "(Hafiar, Subekti, Damayanti, \& Sjoraida, 2015)

Some of the factors that cause the low scientific papers produced by the teachers especially successful scientific papers published in the mass media. One of them is the low interest in reading, in accordance with the following quote:

"The index reading of Indonesian society is still relatively low. This is in accordance with the records of the Organization of Education, Science, and Culture of the United Nations (UNESCO), an index reading of Indonesian people is only 0.001 (2012). That means, from 1,000 people, only one person who read seriously ". http://edukasi.kompas.com

However, the government has sought to improve the community's ability in reading and writing, one of them by establishing the grounds for public readings that provides a variety of reading materials that can be studied and used as a reference by the community, including teachers, the following references proposed by Rumah Persada:

"The Government's attempt to build the literacy community and provide a place to learn and also to hunting information for all people is manifested, among other things, to develop and to empower Community Library (TBM), which generally has been established at the initiative of local community members who are scattered in various regions". (quoted

from

http://www.kompasiana.com/mempopulerkan-

budaya-literasi-melalui-taman-bacaan-masyarakat)

Although some effort has been made by the Government with several parties concerned, but the number of publications by teachers is still not optimal. This is in accordance with the stated by Ali Khomsan that: "Scientific Publications by Indonesian scientists are still low. This shows that the pulse of life science and technology, among the educated is not optimal " (https://nasional.sindonews.com). Scientists, in this case, is to include the teaching profession as academics.

The low levels of publication of teachers' scientific works, especially in the media, led to important information relating to education only for consumption and personal knowledge of teachers as educators, such as information on sex education. The understanding about sex education are:
"Sexual education is an issue of information about human sexuality that are described clearly and correctly, which includes the process of conception, pregnancy until birth, sexual behavior, sexual intercourse, and aspects of health, psychological and social. The issue of sexual education should be provided duly associated with the norms prevailing in society, what is forbidden, what is prevalent and how to do it without breaking the rules prevailing in society "(Nurgiatiningsih, 2010)

Meanwhile, according Luthfie (2009) "Sex education is the information on the question of human sexuality that is described clearly and correctly. That information includes the process of conception, pregnancy until birth, sexual behavior, sexual intercourse, and aspects of health, psychological and social " (Pratama, Hayati, \& Supriatin, 2014). Provision of information about sex education by the school to the students has its own challenges, especially in schools that have specificity as a school for students with special needs or disabilities.

The provision of sex education is the duty and responsibility of parents supported by teachers in schools because, according Nurlaili (2011), "one of the roles of parents as educators is to give early sex education for children. Parents should be aware that children have the right to gain access to the correct information about sexuality "(Yoisangadji, 2016). The other opinion states that:

"The parents responsibility is not only includes or restricted to material needs, but also to the actual cover of all aspects of their life, including aspects of sexual education. Where the understanding and selection of appropriate methods of sexual education will lead children to become human being which is able to keep himself from forbidden deeds and aware of the threats and warnings of immorality as well as having a clear religious grip" (Solihin, 2015)

While the statement mentions that the giving of information about sex education is one of the responsibilities of a teacher quoted from http://nasional.kompas.com, which states that:

As well as sex education at home is the responsibility of parents, sex education in schools are also the responsibility of the teachers, it cannot be delayed any longer if we do not want to see the worse consequences. If the current situation is left alone with regard to sexuality, is tantamount to letting the nation to becoming increasingly not qualified.

Sexuality education is also needed to anticipate the social problems that may occur, this is expressed by J. Hakeng which states that:

"Now, with the rise of sexual cases that afflict children from kindergarten to University, then the demand for sexuality education to provide in schools is increasingly urgent. We see the news in various 
media, there are kindergarten students who sodomized, elementary students who were raped, there are junior high school students who has a hobby to watch pornographic films, there are high school students who abandoned their baby, there are university students who repeatedly done abortion. The case was still more in the field such as homosexuality, masturbation, prostitution, rape, etc. Therefore it is necessary to establish a preventive system to make the social atmosphere could be better"

(http://www.kompasiana.com/www.joebroadcaster.c om/pentingnya-pendidikan-seksualitas-manusia).

However, not many teachers who have been able to publish the results of their thinking and ideas through the mass media. Therefore this study is to reveal the problems of reproductive health education for disabled students through the mass media. This research uses descriptive method with data collection techniques such as interviews and observation and literature study with such instruments as interview guides and observation guides. Interviews and observations conducted on a number of educators in SLB C Cipaganti. As for the data analysis techniques using the qualitative descriptive technique to perform data reduction and categorizing the findings verified through testing the validity of the data source in the form of recheck data.

\section{Constraint in Publishes the Scientific Work in The Mass Media}

There are a number of findings that show a variety of factors which became the cause of the low teachers ' scientific publications in the mass media. One of them relates to a technical problem. Based on the results of FGD known that most of the teachers of SLB Cipaganti not understand the characteristics of writing ideas that can be developed and not yet understand the steps the preparation of writing popular scientific articles. This finding was supported by a statement Ramdan Hamdani, a teacher of SDIT Alamy Subang, West Java, which states that:

"Making a decent article published in the mass media is not easy. Required high sensitivity in capturing the actual issues being warmly discussed. In addition, the delivery of any idea or ideas should be done in a systematic and structured so that the writing made easier to read. Not only that, the language used should also be more communicative. It needs to be done in order to avoid the "distance" between writers and readers". (quoted from http://www.republika.co.id)

In addition, note also that the majority of teachers in SLB Cipaganti argued that they had not understood about how to make the writing seems to have an attraction to read. This means that teachers have to understand the benefits of the use of the supporting instruments that will enhance the attractiveness of a writing in the mass media. In addition, it is noted that almost all the teachers said that they have technical constraints related to the technical article submissions to the mass media, it is because they do not know the mass media that can accommodate their writing, not knowing the rubric of the destination and do not understand how to delivery/correspondence with the media.

As related to psychological problems the data obtained by interviews and discussions include: not have the motivation to disseminate information through the mass media, has not had the courage to start submitting their writing to the media, and their fears of criticism/objection/ridicule from the public reader and their relations. Because school has opportunity to spread values to the society (Aryanti, 2014). Similiar with that, there is an opinion that education institution has to contribute to share culture's values to their students (Komariah \& Subekti, 2016). This is in line with the thought expressed by Supadiyanto Espede Ainun Najib mentioned that:

"The main reason (for the temporary conclusion/hypothesis) why can't they write articles in print media (especially newspapers) until now. One, they claimed to have no ideas or material to be written. Second, they stated couldn't translate ideas into long copy. Third, they say do not know how to make the article technically. Fourth, they do not dare to (do not have the guts) to submit their writing to the mass media editor. Fifth, they fear their work will rejected by editorial print media. Sixth, they were afraid if their work published then will be much criticized from their superior or other parties ". (quoted from http://www.kompasiana.com)

Based on these data, it can produce findings that culminated with the problems faced by teachers of SLB Cipaganti in publishing scientific work in the mass media, including:

\section{TECHNICAL PROBLEMS}

\section{a. TECHNICAL OF WRITING}

- Not understanding the characteristics of writing ideas that can be developed

- Not understanding the preparation steps of writing popular scientific articles

- Not understand the function of supporting instruments

\section{b. TECHNICAL OF DELIVERY}

- Not knowing which mass media can accommodate their posts

- Not knowing the intended sections

- Not understanding how to delivery/correspondence with the media 
2. PSYCHIC ISSUE

- Not motivated to disseminate information through the mass media

- Do not have the courage to start sending writing to the media

- There are fears the criticism/objection/scorn from public readers and relations

Referring to the findings above, it is known that there are a number of obstacles. In principle at the start that the writing culture is still low. Whereas the teaching profession requires scientific publications in order to improve their careers. This is consistent with the findings of the study that "most teachers have the relatively low competence to write. This is demonstrated by the large number of complaints from teachers who found it difficult to climb the ranks because of the constraints of writing. The condition is similar to Budiyono statement (2010) that teachers have not had a culture of writing ". (Setyawati, Larasati, Arifin, Ulumuddin, 2010)

There are a number of ideas generated from a number of studies, to overcome the problems faced by the teachers, among other things: "First they must reading a lot to broaden their horizons to select the issue of what should be written. Besides reading, they also must be assiduous to hear information from various media that inform the actual problems that need to be solved "(Leibo, 2006).

In addition to multiply the reading, to broaden their horizons, writing should become a habit. Habituation can only be done if a person performs an activity continuously. This refers to the opinion of Nanang Yunan Suroso quoted http://edukasi.kompas.com, which states that:

"Developing an idea and cultivate the development of teacher excellence through the activities of writing scientific papers or inspirational writing should be a habitus, habituation. Hernowo, author of "Menjadi Guru yang Mau dan Mampu Membuat Buku", assures us that bind meaning and build character by writing requires continuity and consistency ".

Write scientific papers for the teacher should be accustomed, for writing scientific papers have now become a necessity and the demands that must be met as a consequence of a profession carried, because:

"For the teachers and academics, writing articles in the mass media seems to have become a necessity. In addition to be one of the bases in the Teacher Performance Assessment (PKG) based on Ministerial Regulation No. 35 Year 2010, the existence of teachers in the media indicate that the person concerned actually understand the world of education which became his field of work".
Therefore it is necessary for the various parties to support an increase in the ability to write scientific papers by the teachers through a number of activities. The activities can be carried out by the parties in the form of training, mentoring, partnerships and collaboration, including with universities, or the mass media directly. This meant that teachers were able to improve the quality of his contribution to the nation, not limited to just solely through the process of teaching and learning in the classroom but also through scientific works disseminated to the community through the mass media.

Especially if the information resulting from scientific work will be able to be a valuable information for people who have not received optimal care, such as information on sexual education for adolescents with disability. Because adolescents with disability have the rights for information in the form of proper sexual education for the sake of protection of their live. This is in accordance with the statement that:

"The right of protection, for example, are as protected from domestic violence, sexual abuse, crime, work like an adult, and so forth. Every child, not excluding children with disabilities have the right to protection from violence and crime. The right to participate, every child has the right to express their opinions, have a voice in the family council, has the right to complain, and to choose education according to their interests and talents, and others. Every child, children with disabilities are no exception, has the right to give his opinion, have a purpose in life." (Vani, Raharjo, Hidayat, \& Humaedi, 2014).

\section{CONCLUSIONS AND SUGGESTIONS}

Based on the results and discussions can be found a number of problems that can be categorized as follows: Technical problems, including technical writing and technical writing of delivery. As for which is included in the technical problems of writing are: Not understanding the characteristics of writing ideas that can be developed, Not understanding the preparation steps of writing popular scientific articles, and Not understand the function of supporting instruments. As for the delivery of technical problems include: Not knowing which mass media can accommodate their posts, Not knowing the intended sections and Not understanding how to delivery/correspondence with the media.

As for the psychic issues faced by the educators in disseminating information on reproductive health to students of SLB C in the mass media, such as: Not motivated to disseminate information through the mass media, Do not have the courage to start sending writing to the media, There are fears the criticism/objection/scorn from public readers and relations.

Referring to the conclusion that there are some recommendations can be given, namely: the need for training 
activities in the form of writing techniques workshop of popular scientific works for teachers so that teachers can begin to make scientific articles in accordance with the provisions of writing. This can be done through cooperation with universities that have areas relevant to the field of writing, for example, the faculty of communication sciences. In addition, the process also required assistance so that writing that made the teachers can start distributed to media outlets that can accommodate the popular scientific works so that it can be perceived the real output of the training activities undertaken. Furthermore, this mentoring activity should be run intensively and continuously, so that the activities of publishing scientific papers in the form of writing can be one of a growing culture in educational institutions, so that information about education for students with disabilities can be disseminated to the public as useful knowledge.

\section{REFERENCES}

Aryanti, N. Y. (2014). Pengembangan Identitas Melalui pertemanan Antar Budaya Di Sekolah. Jurnal Kajian Komunikasi, 2/1(1), 93-104.

Hafiar, H., Subekti, P., Damayanti, T., \& Sjoraida, D. F. (2015). Peningkatan Pendidikan Dan Pengembangan Kompetensi Guru Sma Negeri 1 Katapang Melalui Partisipasi Dalam Publikasi Akademis Di Media Massa. Jurnal Dharmakarya, 4(2), 88-92.

Komariah, K., \& Subekti, P. (2016). Penggunaan Media Massa Sebagai Agen Sosialisasi Dinas Kesadaran Masyarakat Akan Pentingnya Imunisasi. Profesi Humas, l(1), 12-21.

Leibo, J. (2006). Manfaat Akademis Dan Kiat Tembus Menulis Dimedia Massa. Jurnal Sosiologi Dilema. Issn : 0215 - 9635, Vol. 18 No. 2

Nurgiatiningsih. (2010). Peran Orangtua Dalam Pendidikan Seksual Remaja Dengan Keterbelakangan Mental. Skripsi. Stain Salatiga.

Pratama, E., Hayati, S., \& Supriatin, E. (2014). Hubungan Pengetahuan Remaja Tentang Pendidikan Seks Dengan Perilaku Seks Pranikah Pada Remaja Di Sma Z Kota Bandung. Ilmu Keperawatan, Ii(2), 149-156.

Saepudin, E. (2013). Literasi Informasi Kesehatan Lingkungan Pada Masyarakat Pedesaan: Studi Deskriptif Di Desa Nagrog Kecamatan Cicalengka. Jurnal Kajian Informasi Dan Perpustakaan, 1(1), 81-89.

Setyawati, N., Larasati., Arifin, Z., Ulumuddin, Arisul. (2010) Ibm Peningkatan Kompetensi Menulis Artikel Media Massa Bermuatan Pendidikan Karakter Untuk Menciptakan Guru Kreatif Dan Produktif Di Kota Semarang Ibm Peningkatan Kompetensi Menulis
Artikel Media Massa Bermuatan Pendidikan Karakter Untuk Menciptakan Guru Kreatif Dan Produktif Di Kota Semarang. Artikel Program Ipteks Bagi Masyarakat (Ibm) . Ikip Pgri Semarang.

Solihin. (2015.). Pendidikan Seks Untuk Anak Usia Dini ( Studi Kasus Di Tk Bina Anaprasa Melati Jakarta Pusat ), (1), 56-74.

Suwanto, S. A. (2015). Analisis Literasi Informasi Pemakai Taman Bacaanmasyarakat. Jurnal Kajian Informasi Dan Perpustakaan, 3(1), 89-100.

Vani, G. C., Raharjo, S. T., Hidayat, E. N., \& Humaedi, S. (2014). Pengasuhan ( Good Parenting ) Bagi Anak Dengan Disabilitas, Vol 4, No, 122-128.

Yoisangadji, F. (2016). Tingkat Pengetahuan Orang Tua Tentang Pendidikan Seks Pada Anak Sekolah Di Sd Negeri Ngrukeman. Skripsi. Universitas Muhammadiyah Yogyakarta.

online:

http://edukasi.kompas.com

http://www.republika.co.id)

http://www.kompasiana.com)

http://www.kompasiana.com/mempopulerkan-budaya-literasimelalui-taman-bacaan-masyarakat)

(http://www.kompasiana.com/www.joebroadcaster.com/pentin gnya-pendidikan-seksualitas-manusia). 